\title{
Development of $\mathrm{Cu} / \mathrm{ZnO} / \mathrm{Al}_{2} \mathrm{O}_{3}$ Catalyst for Dimethyl Ether Synthesis from $\mathrm{CO}-\mathrm{CO}_{2}-\mathrm{H}_{2}$ Mixture
}

\author{
Tomohiro AKIYAMA, Satoshi MACHIDA, ${ }^{1)}$ Hirotaka SATO, ${ }^{2)}$ Atsushi MURAMATSU ${ }^{3)}$ \\ and Jun-ichiro YAGI ${ }^{3)}$
}

Miyagi National College of Technology, Natori, Miyagi-ken, 981-12 Japan.

1) Graduate Student, Tohoku University, Katahira, Aoba-ku, Sendai, Miyagi-ken, 980-77 Japan.

2) Formerly Graduate Student, Tohoku University. Now at Sumitomo Metal Industries, Ltd., Sunayama, Hasaki-machi, Kashima-gun, Ibaraki-ken, 314-02 Japan.

3) Institute for Advanced Materials Processing, Tohoku University, Katahira, Aoba-ku, Sendai, Miyagi-ken, $980-77$ Japan.

(Received on May 22, 1997; accepted in final form on September 8, 1997)

\begin{abstract}
The objective of this study is to develop a catalyst for direct synthesis of dimethyl ether $\left(\left(\mathrm{CH}_{3}\right)_{2} \mathrm{O}, \mathrm{DME}\right)$ from a $\mathrm{CO}-\mathrm{CO}_{2}-\mathrm{H}_{2}$ mixture such as blast furnace gas. For this purpose, precipitated $\mathrm{Cu}-\mathrm{ZnO}-X\left(X=\mathrm{Al}_{2} \mathrm{O}_{3}\right.$, $\mathrm{Cr}_{2} \mathrm{O}_{3}, \mathrm{ZrO}_{2}$ or $\mathrm{Ga}_{2} \mathrm{O}_{3}$ ) were systematically prepared by changing chemical composition and their catalytic activity was measured. For $\mathrm{Cu}-\mathrm{ZnO}-\mathrm{Al}_{2} \mathrm{O}_{3}$ catalyst, compositional research was on two parameters, namely $\mathrm{Cu} / \mathrm{ZnO}$ ratio $(3 / 7-5 / 5)$ and content of $\mathrm{Al}_{2} \mathrm{O}_{3}(0-33.0$ mol\%). The influence of each parameter was estimated by $\mathrm{DME}$ and $\mathrm{MeOH}$ yields for the same catalyst mass. Some $\mathrm{Cu}-\mathrm{ZnO}-\mathrm{Al}_{2} \mathrm{O}_{3}$ catalysts synthesized DME more than $\mathrm{MeOH}$, in which the DME activity was related to specific surface area and existence of broadened $\mathrm{ZnO}$ peaks in XRD patterns. In contrast, three other $\mathrm{Cu}-\mathrm{ZnO}$ catalysts including another oxide $\left(\mathrm{Cr}_{2} \mathrm{O}_{3}, \mathrm{ZrO}_{2}\right.$ or $\mathrm{Ga}_{2} \mathrm{O}_{3}$ ) synthesized only $\mathrm{MeOH}$ without DME. Content of $\mathrm{Al}_{2} \mathrm{O}_{3}$ was more influential on DME synthesis than $\mathrm{Cu} / \mathrm{ZnO}$ ratio. In conclusion, the most active composition of $\mathrm{Cu}-\mathrm{ZnO}-\mathrm{Al}_{2} \mathrm{O}_{3}$ catalyst for $\mathrm{DME}$ synthesis was $\mathrm{Cu} / \mathrm{ZnO}=4 / 6$ with $14.3 \mathrm{~mol} \% \mathrm{Al}_{2} \mathrm{O}_{3}$ and interestingly this composition was included within the range of usual $\mathrm{MeOH}$ synthesis catalysts.
\end{abstract}

KEY WORDS: dimethyl ether; $\mathrm{Cu}-\mathrm{ZnO}-\mathrm{Al}_{2} \mathrm{O}_{3}$; catalyst; blast furnace; energy; industrial waste gas; $\mathrm{CO}-$ $\mathrm{CO}_{2}-\mathrm{H}_{2}$.

\section{Introduction}

As a method of reducing $\mathrm{CO}_{2}$ discharge from a blast furnace (BF), catalytic synthesis of methanol $\left(\mathrm{CH}_{3} \mathrm{OH}\right.$, $\mathrm{MeOH}$ ) has been reported in previous papers. ${ }^{1-4)} \mathrm{MeOH}$ is attracting worldwide attention, because it is not only an important industrial raw material for chemicals such as formaldehyde, ${ }^{5)}$ but is also a clean fuel which burns without emission of $\mathrm{NO}_{x}$ and $\mathrm{SO}_{x}$. For the same reason, dimethyl ether $\left(\left(\mathrm{CH}_{3}\right)_{2} \mathrm{O}, \mathrm{DME}\right)$ is also expected to be a clean energy source with large calorific value and easy transportation properties, the same as LPG. ${ }^{6)}$ In addition, DME synthesis is more advantageous than $\mathrm{MeOH},{ }^{5)}$ from a thermodynamics viewpoint, because its equilibrium yield is much larger. For this reason, we should pay much more attention to DME synthesis. DME can also easily be reformed to $\mathrm{MeOH}$ by hydrolysis, if necessary.

However, DME catalysis from $\mathrm{CO}_{2}$-containing synthesis gas has been rarely published in spite of its significance. Industrially, DME is generally produced from $\mathrm{MeOH}$ by using catalysts such as $\mathrm{Al}_{2} \mathrm{O}_{3}$. Thus, major attention $^{8-12)}$ has been directed to develop a catalyst with the function of dehydration. For synthesizing DME directly from $\mathrm{CO}-\mathrm{CO}_{2}-\mathrm{H}_{2}$ mixtures, not $\mathrm{MeOH}$, we showed in previous studies ${ }^{4,7)}$ that a hybrid catalyst of
$\mathrm{Cu}-\mathrm{ZnO}-\mathrm{Ga}_{2} \mathrm{O}_{3}$ and $\gamma-\mathrm{Al}_{2} \mathrm{O}_{3}$ is relatively effective, in which the two are physically mixed. This new catalyst appealed to the possibility of direct DME synthesis from industrial waste gas containing much $\mathrm{CO}_{2}$, such as $\mathrm{BF}$ offgas. However, it is not easy to uniformly mix different density catalysts in a packed bed reactor and to determine the optimum mixing ratio of the hybrid catalyst. The hybrid catalyst causes another problem for application in a state-of-the-art slurry reactor, because mixture of the two catalysts is difficult in liquid due to their density difference. Thus a single catalyst for DME synthesis from a $\mathrm{CO}-\mathrm{CO}_{2}-\mathrm{H}_{2}$ mixture is very attractive from not only an academic but also an industrial viewpoint.

The aim of this study is to develop catalysts for synthesizing DME from $\mathrm{CO}-\mathrm{CO}_{2}-\mathrm{H}_{2}$ mixtures such as $\mathrm{BF}$ offgas and, particularly, to determine an optimum composition of $\mathrm{Cu}, \mathrm{ZnO}$ and $\mathrm{Al}_{2} \mathrm{O}_{3}$ for high yield of oxygenates (MeOH+DME), in which $\mathrm{Cr}_{2} \mathrm{O}_{3}, \mathrm{ZrO}_{2}$ or $\mathrm{Ga}_{2} \mathrm{O}_{3}$ were also examined instead of $\mathrm{Al}_{2} \mathrm{O}_{3}$.

\section{Materials}

For synthesizing DME from $\mathrm{CO}-\mathrm{CO}_{2}-\mathrm{H}_{2}$ mixtures such as $\mathrm{BF}$ gas, we prepared catalysts of $\mathrm{Cu}-\mathrm{ZnO}-X$ $\left(X=\mathrm{Al}_{2} \mathrm{O}_{3}, \mathrm{Cr}_{2} \mathrm{O}_{3}, \mathrm{ZrO}_{2}, \mathrm{Ga}_{2} \mathrm{O}_{3}\right.$ ) by the precipitation 
Table 1. Chemical composition of fifteen catalysts used. $\mathrm{Cu} / \mathrm{ZnO} / \mathrm{Al}_{2} \mathrm{O}_{3}$ system

\begin{tabular}{cc|c}
\hline $\mathrm{Cu} / \mathrm{ZnO}$ & $\mathrm{Al}_{2} \mathrm{O}_{3} \mathrm{~mol} \%$ & Composition, mol\% \\
\hline $3 / 7$ & 0.0 & $30.0 / 70.0 / 0.0$ \\
& 6.7 & $28.0 / 65.3 / 6.7$ \\
& 14.3 & $25.7 / 60.0 / 14.3$ \\
& 23.1 & $23.1 / 53.8 / 23.1$ \\
$4 / 6$ & 33.0 & $20.0 / 47.0 / 33.0$ \\
& 0.0 & $40.0 / 60.0 / 0.0$ \\
& 6.7 & $37.3 / 56.0 / 6.7$ \\
& 14.3 & $34.3 / 51.4 / 14.3$ \\
$5 / 5$ & 23.1 & $30.8 / 46.1 / 23.1$ \\
& 6.7 & $46.7 / 46.7 / 6.7$ \\
& 14.3 & $42.9 / 42.9 / 14.3$ \\
& 23.1 & $38.5 / 38.5 / 23.1$ \\
\hline $\mathrm{Cu} / \mathrm{ZnO} / \mathrm{Oxide}\left(\mathrm{Cr}_{2} \mathrm{O}_{3}, \mathrm{ZrO}_{2}, \mathrm{Ga}_{2} \mathrm{O}_{3}\right)$ & system \\
\hline $\mathrm{Cu} / \mathrm{ZnO}$ & $\mathrm{Oxide} \mathrm{mol} \%_{2}$ & $\mathrm{Composition,} \mathrm{mol \%}$ \\
\hline \multirow{2}{*}{$3 / 7$} & 14.3 & $25.7 / 60.0 / 14.3$ \\
\hline
\end{tabular}

method. Chemical composition of the catalysts prepared is given in Table 1. Twelve catalysts of the $\mathrm{Cu}-\mathrm{ZnO}-$ $\mathrm{Al}_{2} \mathrm{O}_{3}$ system were prepared, in which additive content of alumina was systematically changed under three different ratios of $\mathrm{Cu} / \mathrm{ZnO}$. In addition, three catalysts with different oxides $\left(\mathrm{Cr}_{2} \mathrm{O}_{3}, \mathrm{ZrO}_{2}, \mathrm{Ga}_{2} \mathrm{O}_{3}\right)$ instead of alumina were also prepared for comparison. The preparation procedure of the catalysts was reported in detail elsewhere. ${ }^{2,4.5)}$ For the $\mathrm{Cu}-\mathrm{ZnO}-\mathrm{Al}_{2} \mathrm{O}_{3}$ catalyst, the procedure framework is as follows;

(1) Three commercial chemicals of $\mathrm{Cu}\left(\mathrm{NO}_{3}\right)_{2} \cdot 3 \mathrm{H}_{2} \mathrm{O}$, $\mathrm{Zn}\left(\mathrm{NO}_{3}\right)_{2} \cdot 6 \mathrm{H}_{2} \mathrm{O}$ and $\mathrm{Al}\left(\mathrm{NO}_{3}\right)_{3} \cdot 9 \mathrm{H}_{2} \mathrm{O}$ are first dissolved in distilled water at room temperature, to obtain aqueous solutions of $1 \mathrm{~mol} / \mathrm{dm}^{3}$ with the desired molecular ratio of the metallic elements.

(2) The obtained solution and $0.7 \mathrm{~mol} / \mathrm{dm}^{3}$ sodium carbonate $\left(\mathrm{Na}_{2} \mathrm{CO}_{3} \cdot 10 \mathrm{H}_{2} \mathrm{O}\right)$ solution are mixed at $353 \mathrm{~K}$ all at once, to precipitate the carbonates of $\mathrm{Cu}, \mathrm{Zn}$ and Al. The precipitate, recovered by filtration, is sintered at $673 \mathrm{~K}$ after sufficient drying at $393 \mathrm{~K}$.

(3) Next, the sinter is crushed in a mortar and particles of size $0.35-0.84 \mathrm{~mm}$ are separated by sieving for packing into a reaction tube.

(4) The packed catalyst is finally reduced by pure hydrogen at $653 \mathrm{~K}$ just before the experiments.

\section{Method}

Figure 1 shows a schematic diagram of an experimental system for DME synthesis, consisting of three parts: gas supplier, fixed-bed reactor and gas analyzer. The molar ratio of feed gas excluding nitrogen, $\mathrm{CO} / \mathrm{CO}_{2} / \mathrm{H}_{2}=4 / 4 / 1$ (molar basis), corresponds to operating data ${ }^{1)}$ of a $\mathrm{BF}$ with natural gas injection of $50 \mathrm{Nm}^{3}$ per ton-hot-metal. Nitrogen was added to the feed gas to avoid $\mathrm{CO}_{2}$ liquification in the cylinder so the composition of the actual feedgas is $\mathrm{CO} / \mathrm{CO}_{2} / \mathrm{H}_{2} / \mathrm{N}_{2}=35 / 35 / 8.7 / 21.3$. After the feedgas was introduced, outlet gas from the fixedbed reactor was analyzed by two kinds of gas chromatography: FID (Flame Ionization Detector) for DME,

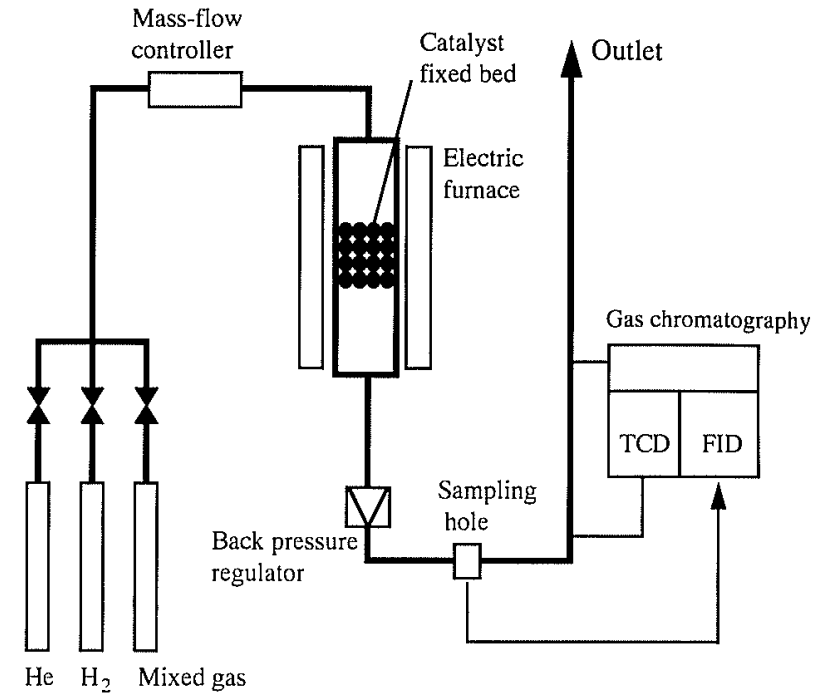

Fig. 1. Experimental apparatus for dimethyl ether and methanol synthesis.

FID: Flame Ionization Detector TCD: Thermal Conductivity Detector

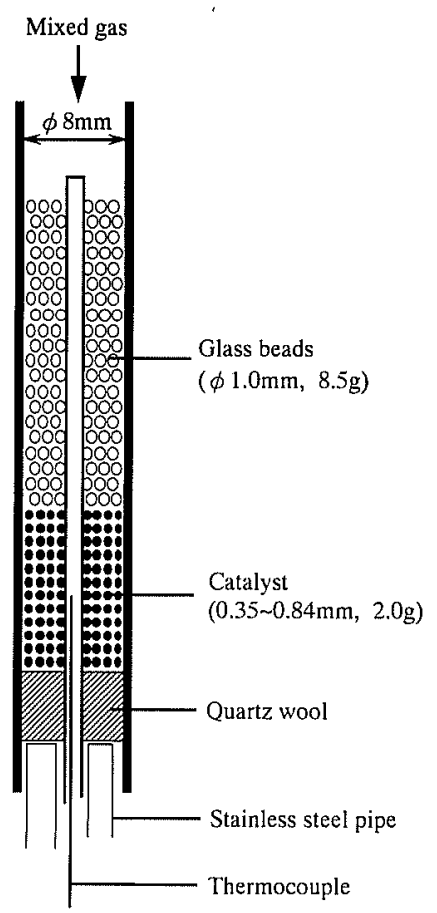

Fig. 2. Schematic representation of catalytic fixed bed reactor.

$\mathrm{MeOH}$ and hydrocarbon(HC, mainly methane), and TCD (Thermal Conductivity Detector) for $\mathrm{CO}, \mathrm{CO}_{2}$, $\mathrm{H}_{2}$ and $\mathrm{N}_{2}$.

An enlargement of the reactor is shown in Fig. 2. The reactor employed was made of SUS316 stainless steel tube with $10 \mathrm{~mm}$ outer diameter and $8 \mathrm{~mm}$ inner diameter. The prepared catalyst was fixed at the middle position of the uniform temperature zone, on which glass beads were placed for preheating the feed gas and for obtaining radially-uniform flow. To measure temperature changes of the catalyst during the experiment, we introduced a CA type thermocouple, $1 \mathrm{~mm}$ in outer diameter, into the bed. The experimental conditions of this study were $523 \mathrm{~K}, 1.0 \mathrm{MPa}$ inlet pressure and 


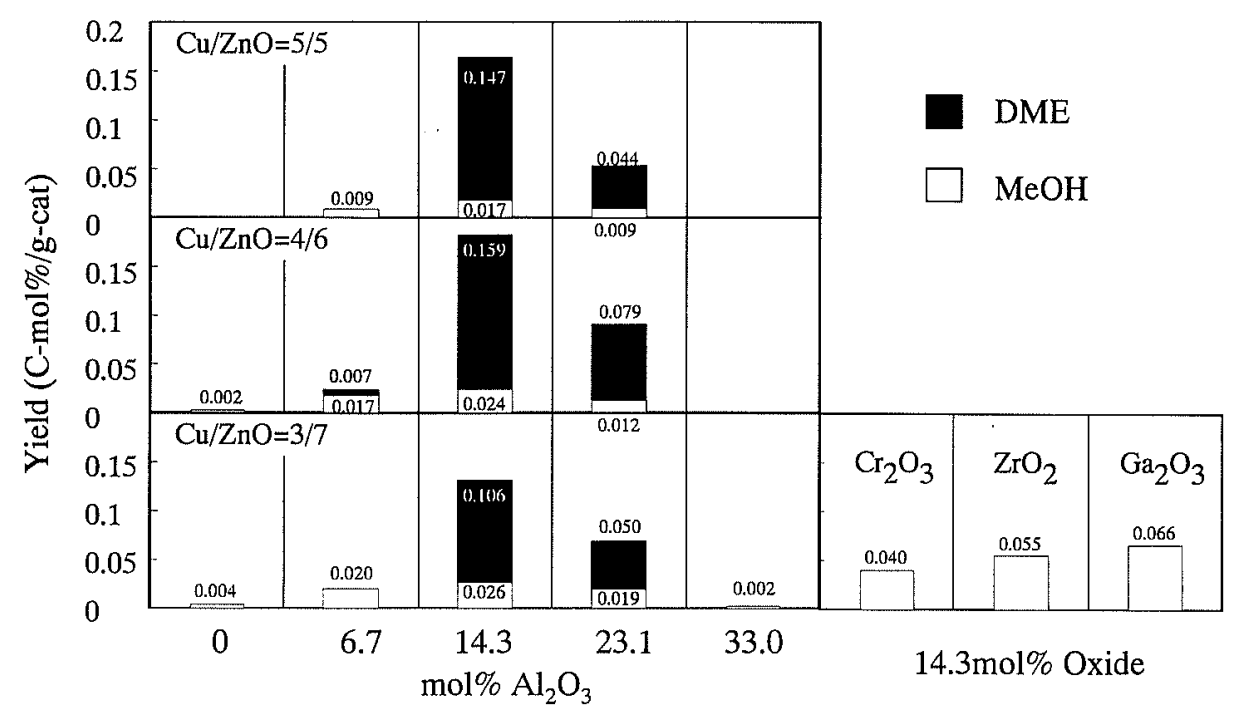

Fig. 3. Measured yields of methanol and dimethyl ether for all catalysts.

$1.0 \times 10^{-6} \mathrm{~m}^{3} / \mathrm{sec}$ (STP) flowrate of the feed gas. These were determined based on our previous studies. ${ }^{2,3)}$ The measurements were continued until outlet gas composition reached a steady state.

\section{Results and Discussion}

All monitored components of the outlet gas $\left(\mathrm{CO}, \mathrm{CO}_{2}\right.$, $\mathrm{H}_{2}, \mathrm{MeOH}, \mathrm{DME}, \mathrm{HC}, \mathrm{N}_{2}$ ) reached constant values with negligible further temperature changes after approximately $6 \mathrm{~h}$. The obtained concentrations of $\mathrm{MeOH}$ and DME for each catalyst were then defined as their final yields. Figure 3 shows bar graphs of evaluated yields of $\mathrm{DME}$ and $\mathrm{MeOH}$, for all of the catalysts prepared. Here, $\mathrm{Cu} / \mathrm{ZnO}$ ratio in the catalysts in the horizontal direction of the graph is constant and the three rows of the graph are for different $\mathrm{Cu} / \mathrm{ZnO}$ ratios: $3 / 7,4 / 6$ and $5 / 5$. The bar height indicates the DME and $\mathrm{MeOH}$ yields. Obviously, some catalysts of $\mathrm{Cu}-\mathrm{ZnO}-\mathrm{Al}_{2} \mathrm{O}_{3}$ gave good yields of DME with little $\mathrm{MeOH}$ synthesis although only $\mathrm{MeOH}$ is normally synthesized from $\mathrm{CO}-\mathrm{H}_{2}$ gas as mentioned later. The results suggest significant influence of $\mathrm{Al}_{2} \mathrm{O}_{3}$ content on DME yields, in comparison to $\mathrm{Cu} / \mathrm{ZnO}$ ratio. The highest yield of $\mathrm{DME}+\mathrm{MeOH}$ was given by the catalyst of $14.3 \% \mathrm{Al}_{2} \mathrm{O}_{3}$ with $\mathrm{Cu} / \mathrm{ZnO}=$ $4 / 6$. Performance of this catalyst $(0.159+0.024=0.183 \mathrm{C}$ mol\%/g-cat.) is the same level as the hybrid catalyst $(0.160+0.018=0.178 * \mathrm{C}$-mol\%/g-cat. $)$. In contrast, addition of oxides of $\mathrm{Cr}_{2} \mathrm{O}_{3}, \mathrm{ZrO}_{2}$ and $\mathrm{Ga}_{2} \mathrm{O}_{3}$ instead of $\mathrm{Al}_{2} \mathrm{O}_{3}$ did not cause DME generation, although $\mathrm{Cu}-$ $\mathrm{ZnO}-\mathrm{Ga}_{2} \mathrm{O}_{3}$ showed the highest yield of $\mathrm{MeOH}$ among all of the catalysts.

To make clear the effects of $\mathrm{Al}_{2} \mathrm{O}_{3}$ content and $\mathrm{Cu} /$ $\mathrm{ZnO}$ ratio in the $\mathrm{Cu}-\mathrm{ZnO}-\mathrm{Al}_{2} \mathrm{O}_{3}$ system, we redrew data in the following two figures. Figure $\mathbf{4}$ shows the effect of $\mathrm{Al}_{2} \mathrm{O}_{3}$ content on $\mathrm{DME}$ and $\mathrm{MeOH}$ yields with $\mathrm{Cu}$ / $\mathrm{ZnO}=3 / 7$. The sharp rise in DME yield indicates strong sensitivity to $\mathrm{Al}_{2} \mathrm{O}_{3}$ content, in comparison to the $\mathrm{MeOH}$ yield. Both peaks of DME and $\mathrm{MeOH}$ curves were inter-

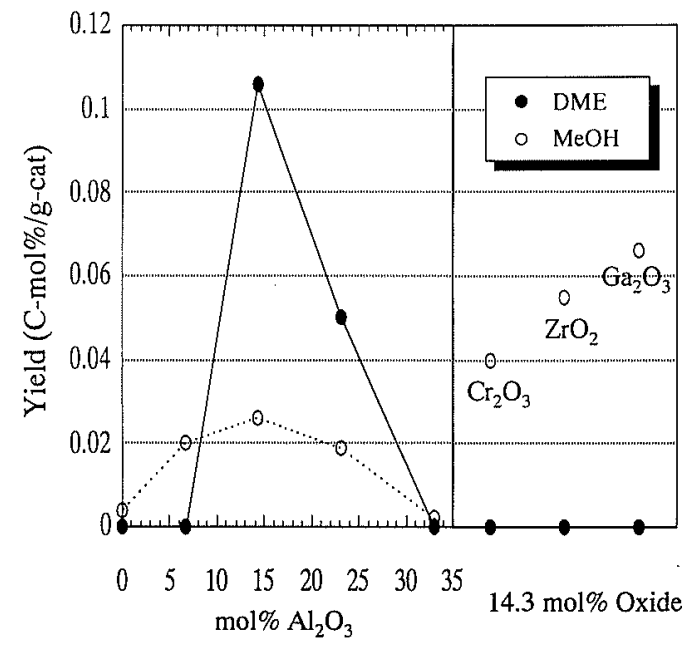

Fig. 4. Effect of alumina content on dimethyl ether and methanol yields over catalysts of $\mathrm{Cu} / \mathrm{ZnO}=3 / 7$, together with other oxides.

estingly identically located at $14.3 \mathrm{~mol} \% \mathrm{Al}_{2} \mathrm{O}_{3}$. Similar tendencies were also observed for the other $\mathrm{Cu} / \mathrm{ZnO}$ ratios of $4 / 6$ and $5 / 5$. This is explained well by the concept $^{7)}$ that DME is produced by a series reaction via $\mathrm{MeOH}$ synthesis (BF gas $\rightarrow \mathrm{MeOH} \rightarrow \mathrm{DME}$ ).

Figure 5 shows the effect of $\mathrm{Cu} / \mathrm{ZnO}$ ratio on yields of DME and MeOH. Peaks of DME curves were observed at $\mathrm{Cu} / \mathrm{ZnO}=4 / 6$, with weak dependence on $\mathrm{Cu} /$ $\mathrm{ZnO}$ ratio. Strangely, $\mathrm{Cu}-\mathrm{ZnO}$ catalysts without $\mathrm{Al}_{2} \mathrm{O}_{3}$ showed little activity for DME and $\mathrm{MeOH}$ syntheses, in spite of experimental reports ${ }^{8)}$ claiming that $\mathrm{Cu}-\mathrm{ZnO}$ is effective for synthesizing $\mathrm{MeOH}$ from mixtures of $\mathrm{CO}$, $\mathrm{H}_{2}$ and a little $\mathrm{CO}_{2}$. In addition, they claimed no effect of $\mathrm{Cu}-\mathrm{ZnO}-\mathrm{Al}_{2} \mathrm{O}_{3}$ catalyst on DME synthesis at all, although the chemical composition of industrial catalysts $\left(\mathrm{Cu}: 12-66 \mathrm{~mol} \%, \mathrm{ZnO}: 17-62 \mathrm{~mol} \%, \mathrm{Al}_{2} \mathrm{O}_{3}: 4\right.$ $38 \mathrm{~mol} \%)$ covers this study's best catalyst $(34.3 / 51.4 /$ 14.3). This is mainly due to syngas composition (CO$\mathrm{CO}_{2}-\mathrm{H}_{2}$ ). Regarding the relationship between syngas

* This value was estimated from Ref. 7) by uniforming a unit. 


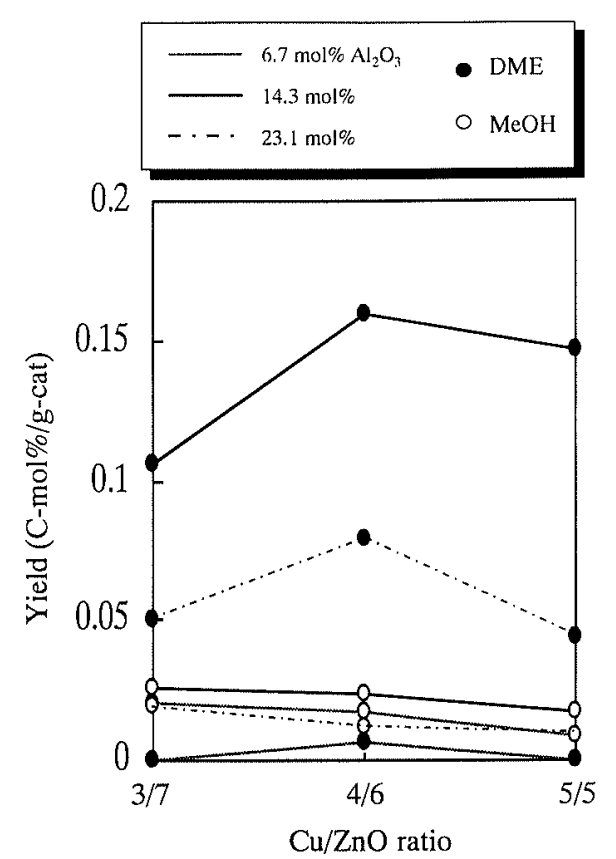

Fig. 5. Effect of $\mathrm{Cu} / \mathrm{ZnO}$ ratio on yields of dimethyl ether and methanol.

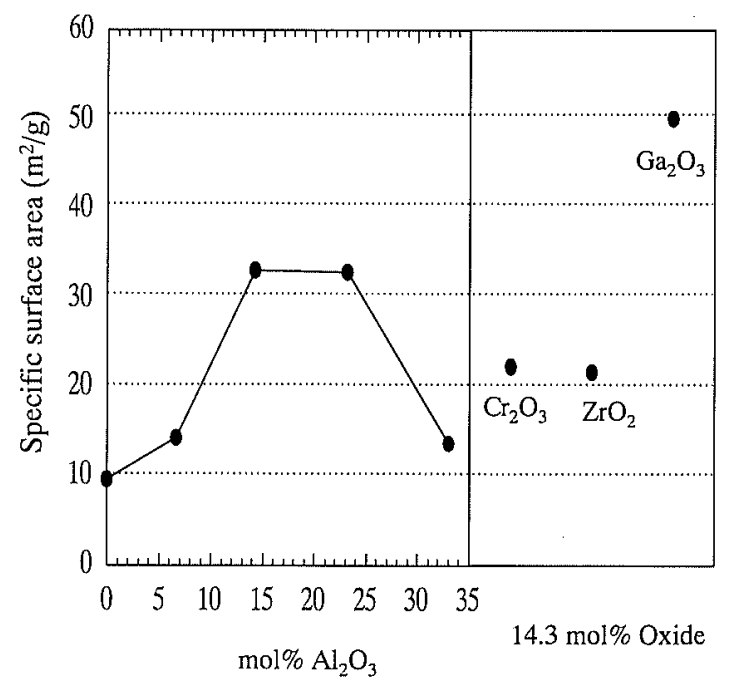

Fig. 6. Effect of $\mathrm{Al}_{2} \mathrm{O}_{3}$ content and oxides on specific surface area of catalysts with molar ratio of $\mathrm{Cu} / \mathrm{ZnO}=3 / 7$.

composition and catalyst composition, a noteworthy result was recently reported by Fujita and coworkers. ${ }^{12)}$ They examined the catalyst mechanism of $\mathrm{Cu}-\mathrm{ZnO}$ under $\mathrm{CO}-\mathrm{H}_{2}$ and $\mathrm{CO}_{2}-\mathrm{H}_{2}$ by means of diffuse reflectance FT-IR spectroscopy. The result demonstrated that $\mathrm{Cu}$ promotes $\mathrm{CO}_{2}$ conversion to $\mathrm{MeOH}$ and $\mathrm{ZnO}$ promotes $\mathrm{CO}$ conversion. This suggests that the $\mathrm{CO} / \mathrm{CO}_{2}$ ratio of syngas would have significant influence on the optimum catalyst composition in the $\mathrm{Cu} / \mathrm{ZnO}$ system. Therefore a similar study should be extended to $\mathrm{CO}-\mathrm{CO}_{2}-\mathrm{H}_{2}$ mixtures for constructing an advanced catalyst theory.

Figure 6 shows measured surface area of the catalysts of $\mathrm{Cu} / \mathrm{ZnO}=3 / 7$. The measured specific surface area showed strong $\mathrm{Al}_{2} \mathrm{O}_{3}$-content dependence. Interestingly, this result can explain well the catalyst property of the $\mathrm{Cu}-\mathrm{ZnO}-\mathrm{Al}_{2} \mathrm{O}_{3}$ system (see Fig. 3). That is, we can conclude that the catalysts with large surface area cause
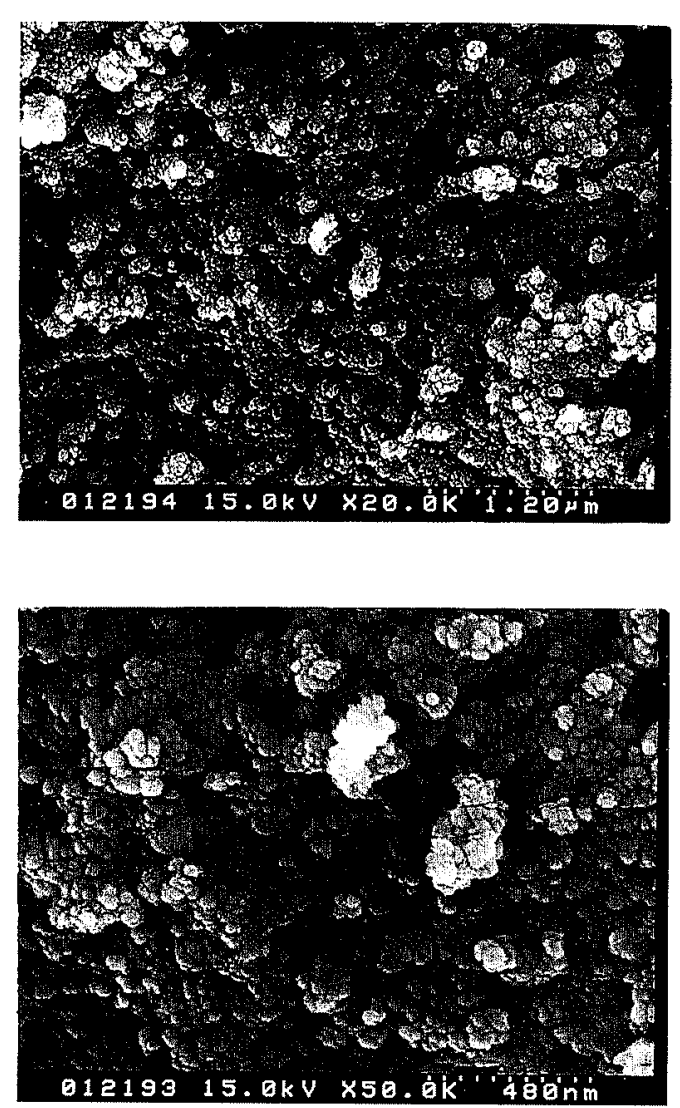

Fig. 7. SEM photographs of $14.3 \mathrm{~mol} \% \mathrm{Al}_{2} \mathrm{O}_{3}$ catalysts with $\mathrm{Cu} / \mathrm{ZnO}=4 / 6$. (Top: $\times 20 \mathrm{k}$, Bottom: $\times 50 \mathrm{k})$

high yields of DME. The surface area of 14.3 and $23.1 \mathrm{~mol} \% \mathrm{Al}_{2} \mathrm{O}_{3}$ catalysts (approximately $33 \mathrm{~m}^{2} / \mathrm{g}$ ) were more three times higher in comparison to the catalyst without $\mathrm{Al}_{2} \mathrm{O}_{3}$. Judging from scanning electron microscopy (SEM) observations (Fig. 7), this difference of surface area is induced by the surface structure of the obtained catalysts, because the $14.3 \mathrm{~mol} \% \mathrm{Al}_{2} \mathrm{O}_{3}$ catalyst has a rough skin with fine particles. Conversely speaking, control of nucleus generation in catalyst preparation for increasing the effective surface area of the catalyst is crucial. Similarly, the $14.3 \mathrm{~mol}_{0} \mathrm{Ga}_{2} \mathrm{O}_{3}$ catalyst showed large surface area and good catalyst properties. However, this applied to only $\mathrm{MeOH}$ synthesis, not DME synthesis.

Figure 8 shows XRD (X-ray diffraction) patterns of the $\mathrm{Cu}-\mathrm{ZnO}-\mathrm{Al}_{2} \mathrm{O}_{3}$ catalysts used, in which three substances of $\mathrm{Cu}, \mathrm{ZnO}$ and $\mathrm{ZnAl}_{2} \mathrm{O}_{4}$ were detected as main peaks. Peaks of $\mathrm{Al}$ or $\mathrm{Al}_{2} \mathrm{O}_{3}$ never appeared in spite of our expectation. With increasing $\mathrm{Al}_{2} \mathrm{O}_{3}$ from 0 to 14.3 $\mathrm{mol} \%$, peaks of $\mathrm{Cu}$ and $\mathrm{ZnO}$ were broadened and their heights became smaller. In this range, the catalysts became more active for DME and $\mathrm{MeOH}$ synthesis with increasing $\mathrm{Al}_{2} \mathrm{O}_{3}$ (see Fig. 4). In contrast, 23.1 and $33.0 \mathrm{~mol} \% \mathrm{Al}_{2} \mathrm{O}_{3}$ catalysts showed $\mathrm{ZnAl}_{2} \mathrm{O}_{4}$ peaks instead of $\mathrm{ZnO}$ peaks, however its peak width was very broad. In addition, the $\mathrm{Cu}$ peaks of the $33.0 \mathrm{~mol} \%$ catalyst became very weak. According to these results, we can expect that the optimum composition of the catalyst would range between 14.3 and $23.1 \mathrm{~mol} \%$ $\mathrm{Al}_{2} \mathrm{O}_{3}$. As for the mechanism of DME direct synthesis 


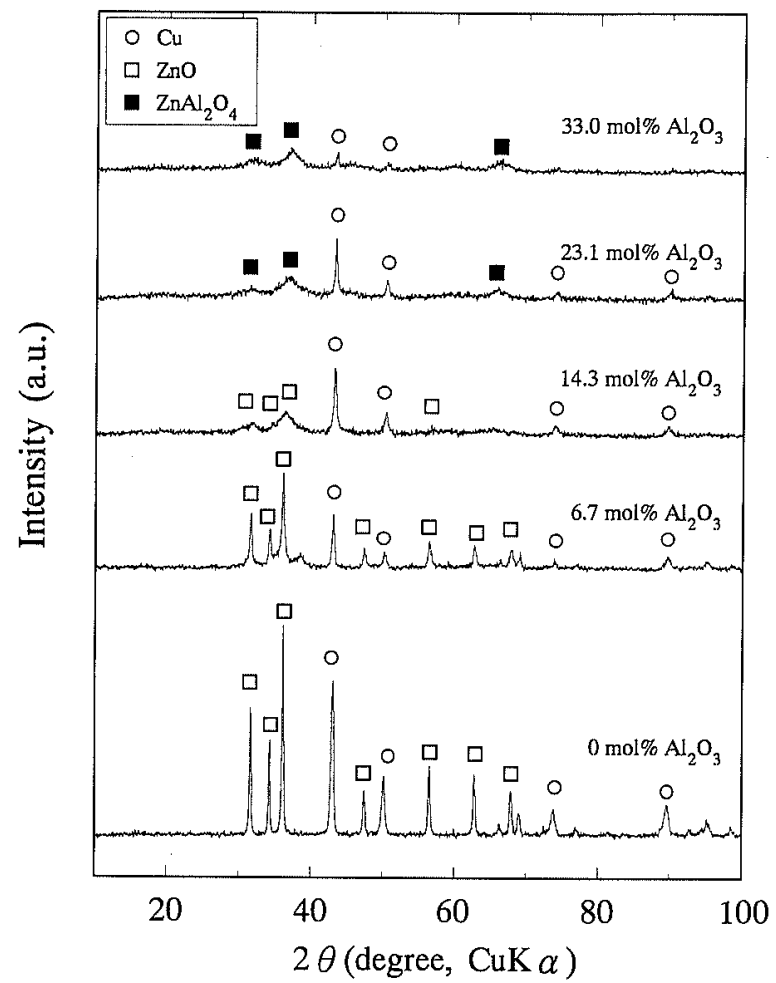

Fig. 8. XRD patterns of catalysts with molar ratio of $\mathrm{Cu}$ / $\mathrm{ZnO}=3 / 7$

from $\mathrm{CO}-\mathrm{CO}_{2}-\mathrm{H}_{2}, \mathrm{Al}_{2} \mathrm{O}_{3}$ micro-structure must be a key point as mentioned above. Microscopic research of catalyst structure is also needed in the future.

\section{Conclusion}

Fifteen kinds of $\mathrm{Cu}-\mathrm{ZnO}-\mathrm{Al}_{2} \mathrm{O}_{3}$ and $\mathrm{Cu}-\mathrm{ZnO}-\mathrm{Oxide}$ $\left(\mathrm{Cr}_{2} \mathrm{O}_{3}, \mathrm{ZrO}_{2}, \mathrm{Ga}_{2} \mathrm{O}_{3}\right)$ catalysts were systematically studied for direct synthesis of DME from $\mathrm{CO}-\mathrm{CO}_{2}-\mathrm{H}_{2}$ mixture. The experimental conditions were $523 \mathrm{~K}, 1.0$ $\mathrm{MPa}$ pressure and $2.0 \mathrm{~g}$ catalyst weight. The following conclusions were drawn:

(1) The most noteworthy finding is the significant catalytic activity of $\mathrm{Cu}-\mathrm{ZnO}-\mathrm{Al}_{2} \mathrm{O}_{3}$ in DME synthesis, not $\mathrm{MeOH}$, from $\mathrm{CO}-\mathrm{CO}_{2}-\mathrm{H}_{2}$ mixture. The catalyst of $34.3 \mathrm{Cu}-51.4 \mathrm{ZnO}-14.3 \mathrm{Al}_{2} \mathrm{O}_{3}(\mathrm{Cu} / \mathrm{ZnO}=4 / 6$ (mole basis)) showed the best activity for DME synthesis.

(2) Addition of oxides other than $\mathrm{Al}_{2} \mathrm{O}_{3}$ to the $\mathrm{Cu}-$ $\mathrm{ZnO}$ system was not effective for DME synthesis at all, although $\mathrm{Cu}-\mathrm{ZnO}-\mathrm{Ga}_{2} \mathrm{O}_{3}$ catalyst showed the best activity for $\mathrm{MeOH}$ synthesis.

(3) The catalytic mechanism of the system of $\mathrm{Cu}-$ $\mathrm{ZnO}-\mathrm{Al}_{2} \mathrm{O}_{3}$ is still not well explained. However, catalysts showed strong relationship between DME activity and surface area, and XRD peaks of $\mathrm{ZnO}$ in active catalysts tend to be broadened without $\mathrm{Zn}$ and $\mathrm{ZnAl}_{2} \mathrm{O}_{4}$ peaks.

\section{Acknowledgments}

The authors would like to thank Mr.Peter Austin for his careful review of the manuscript with grammatical corrections. This work was supported by grant-in-aid for scientific research (No. 06246103) from the Ministry of Education, Science and Culture, Japan.

\section{REFERENCES}

1) T. Akiyama, H. Sato, A. Muramatsu and J. Yagi: ISIJ Int., 33 (1993), 1136.

2) A. Muramatsu, H. Sato, T. Akiyama and J. Yagi: ISIJ Int., 33 (1993), 1144.

3) H. Sato, T. Akiyama, A. Muramatsu, T. Sugimoto and J. Yagi: J. Jpn. Pet. Inst., 38 (1995), 390.

4) H. Sato: Ph. D. Thesis, Tohoku University, (1996).

5) H. Hover: Ullmann's Encyclopedia of Industrial Chemistry, A8 (1989), 541.

6) Y. Ohno: Personal communication, (1996).

7) S. Machida, T. Akiyama, A. Muramatsu and J. Yagi: ISIJ Int,, 37 (1997), 531.

8) R. G. Harman, K. Klier, G. W. Simmons, B. P. Finn, J. B. Bulko and T. P. Kobylinski: J. Calal., 56 (1979), 407.

9) B. Peplinski, W. E. S. Unger and I. Grohmann: Appl. Surf. Sci., 62 (1992), 115.

10) R. Burch, S. E. Golunski and M. S. Spencer: J. Chem Soc. Faraday Trans., 86(15) (1990), 2683

11) I. Nakamura, T. Fujitani, T. Uchijima and J. Nakamura: J. Vac. Sci. Technol, A14(3) (1996), 1464

12) S. Fujita, M. Usui, H. Ito and N. Takezawa: J. Catal., 157 (1995), 403. 